\title{
The Oxidation of Fatty Acids by Spores of Penicillium roqueforti
}

\author{
By R. C. LAWRENCE* \\ The Dairy Research Institute (N.Z.), Palmerston North, New Zealand
}

(Received 21 January 1966)

\begin{abstract}
SUMMARY
The ability of washed spores of Penicillium roqueforti to oxidize fatty acids decreased markedly with age but was restored by adding specific sugars and amino acids. Only the $\mathrm{C}_{6}$ to $\mathrm{C}_{12}$ fatty acids were oxidized to the corresponding methyl ketone with one less carbon atom. The yield of methyl ketone between $\mathrm{pH} \mathbf{5 . 5}$ and $7 \cdot 0$ decreased progressively from a maximum of $75 \%$ from octanoic acid to zero from myristic acid. The small amounts of metabolic carbon dioxide evolved greatly stimulated the oxidation of $\mathrm{C}_{10}$ and $\mathrm{C}_{12}$ fatty acids. The addition of sodium azide, 2,4-dinitrophenol (DNP) and certain divalent metallic ions, but not chloramphenicol, inhibited the oxidation of fatty acids. Oxidation was preceded by a lag period which was lengthened by increasing the fatty acid concentration or by decreasing the concentration of spores. Since cell-free extracts of spores were able to oxidize fatty acids, the lag phase with whole spores appears to be due to the absence of active transport systems. This is also indicated by the elimination of the lag phase by pre-incubation with octanoic acid but not by pre-incubation with glucose or casamino acids. The possible significance of methyl ketone formation in fatty acid metabolism is discussed.
\end{abstract}

\section{INTRODUCTION}

It is well established that growing cultures of certain fungi oxidize short chain fatty acids to the corresponding methyl ketone with one less carbon atom (Stokoe, 1928; Thaler \& Geist, 1939; Franke \& Heinen, 1958). However, washed suspensions of spores of Penicillium roqueforti produced very low yields of heptan-2-one when incubated with octanoic acid as sole carbon substrate (Gehrig \& Knight, 1963). This finding was confirmed by Lawrence (1965a) who showed however that the addition of specific sugars and amino acids greatly stimulated both oxygen uptake and formation of heptan-2-one. These preliminary results suggested that certain compounds were metabolized more readily than others to yield either energy or metabolic products essential for the termination of the dormant state of the spore, that is, for the activation process, and that the spatial arrangement of hydrogen atoms and hydroxyl groups round the carbon atoms in the stimulating sugars appeared to have special significance.

The physiological importance of methyl ketone formation is not clear. Stokoe (1928) postulated that the abnormal oxidation of fatty acids to methyl ketones by mycelium is a result of the toxic effect of the acid on the fungus. Since the mycelium

* Present address: The National Institute for Research in Dairying, Shinfield, Reading. 
of Aspergillus niger possesses a constitutive $\beta$-oxo acid decarboxylase, Franke, Platzeck \& Eichhorn (1962) concluded that the removal of $\beta$-oxo acids is important to fungal cells and that the methyl ketones formed might serve as non-specific inhibitors against other more sensitive micro-organisms. Gehrig \& Knight (1963), on the other hand, attributed the very low yields of heptan-2-one obtained when octanoic acid is oxidized by spores of Penicillium roqueforti to the possibility that the ketone-forming system is inducible and the need for a critical concentration of $\beta$-oxo acid before methyl ketone is formed.

The present paper describes the oxidation of the $\mathrm{C}_{\mathbf{4}}$ to $\mathrm{C}_{\mathbf{1 4}}$ fatty acids by spores of Penicillium roqueforti under various experimental conditions. The oxidation of octanoic acid was studied more fully in an attempt to determine the mechanism and possible significance of methyl ketone formation.

\section{METHODS}

Chemicals. Solutions of the salts of the fatty acids (Applied Science Laboratories, Inc., State College, Pa., U.S.A.) were prepared by adding potassium hydroxide and adjusting to the required concentration. Amino acids and sugars (British Drug Houses Ltd.) were dissolved in water and Seitz filtered (Ford's Sterimats, A. Gallenkamp and Co. Ltd.). Chloramphenicol was obtained from Parke, Davis and Co., Detroit, Michigan, U.S.A.

$\left[1-{ }^{14} \mathrm{C}\right]$ Octanoic acid and $\left[n-{ }^{14} \mathrm{C}\right]$ hexadecane were obtained from the Radiochemical Centre, Amersham, Buckinghamshire, England. $\left[2-{ }^{14} \mathrm{C}\right]$ Octanoic acid was synthesized from $\left[{ }^{2-14} \mathrm{C}\right]$ diethylmalonate by a micro-adaptation of the method of Reid \& Ruhoff (1944). The purity of the acid was checked directly by co-chromatography with a pure sample of octanoic acid on a gas chromatograph with a column packing of $20 \%(\mathrm{w} / \mathrm{w})$ diethylethylene glycol succinate and $2 \% \mathrm{H}_{3} \mathrm{PO}_{4}$ on $60-80$ mesh acid-washed 'Celite 545' (Metcalf, 1960).

Phosphate buffers were prepared by adjusting $\mathbf{0} \cdot \mathbf{1} \mathbf{M}-\mathrm{KH}_{2} \mathrm{PO}_{4}$ to the desired $\mathrm{pH}$ value with $0 \cdot 1 \mathrm{M}-\mathrm{K}_{2} \mathrm{HPO}_{4}$ or $\mathbf{0} \cdot \mathbf{1} \mathbf{\mathrm { M }}-\mathrm{H}_{3} \mathrm{PO}_{4}$.

Preparation of spore suspensions. Spores of Penicillium roqueforti, strain 6989, obtained from the American Type Culture Collection, Washington, D.C., were grown on slopes of Czapek-Dox agar (Oxoid) at $22^{\circ}$. After 4-5 days of incubation the spores were harvested by adding distilled water and scraping them with a sterile needle from the surface of the agar. They were separated from small pieces of agar and mycelium by filtering the suspension through two layers of sterile cheesecloth. The spores were then collected on a Millipore filter, type AA white, $1.5 \mathrm{~cm}$. diameter, $0.5 \mu$ (Millipore Filter Corporation), washed with distilled water and transferred to $0 \cdot 1 \mathrm{M}$-sodium phosphate buffer. The suspension was adjusted by using a haemocytometer to a final concentration of $1.5 \times 10^{9}$ spores/ml. For prolonged incubations streptomycin $(0.5 \mathrm{mg} . / \mathrm{ml}$.) was added to prevent bacterial growth. Preliminary experiments showed that streptomycin had no effect upon the oxidation of fatty acids by the spore suspensions.

While exogenous phosphate was not required for the oxidation of fatty acids, it was necessary to buffer the spore suspension since the uptake of the acids raised the $\mathrm{pH}$ value above $\mathrm{pH} \mathbf{7 \cdot 0}$, resulting in a marked decrease in the rate of oxidation.

Effect of growth medium. The ability of spores to oxidize fatty acids to the 
corresponding methyl ketone was not found to be significantly dependent upon the growth medium (Czapek-Dox, potato glucose and malt agars were tested). Attempts to grow spores on peptone agars containing no carbohydrate were unsuccessful.

Cell-free extracts of spores. Sufficient $0.05 \mathrm{M}$-phosphate $+0.05 \mathrm{M}$-sucrose buffer (pH 6.8) was added at $4^{\circ}$ to spores $(1 \mathrm{~g}$. wet wt.) and acid washed sand $(2 \mathrm{~g}$.$) in a$ pre-cooled mortar to form a thick paste. The paste was ground for $5 \mathrm{~min}$., buffer added to about $10 \mathrm{ml}$. and the suspension centrifuged for $10 \mathrm{~min}$. at $1200 \mathrm{~g}$.

Measurement of oxygen uptake. Manometric measurements of respiration were made by the direct Warburg method at $27^{\circ}$. The total volume in each flask was usually $\mathbf{3 . 2} \mathrm{ml}$., including $\mathbf{0 . 2} \mathrm{ml}$. of $20 \%(\mathrm{w} / \mathrm{v}) \mathbf{K O H}$ in the centre well. Salts of acids with more than ten carbon atoms were warmed to $45^{\circ}$ before addition to the side arm of a Warburg flask, to ensure that all the material was in solution.

Estimation of methyl ketones. The methyl ketone concentration was determined at intervals during the experiments by adding $1 \mathrm{ml}$. of the contents of a Warburg flask into $2 \mathrm{ml}$. of 2,4-dinitrophenylhydrazine (DNP hydrazine, $2 \mathrm{~g}$. $/ \mathrm{l} .2 \mathrm{~N}-\mathrm{HCl}$ ) in a stoppered test tube. After $30 \mathrm{~min}$, the 2,4-DNP hydrazine was extracted and the methyl ketone estimated by the method previously described (Lawrence, 1965 b). The recovery of up to $\mathbf{5 \cdot 0} \mu$ moles of the ketones as their 2,4-DNP hydrazones/mI. was quantitative.

Identification of methyl ketones as their 2,4-DNP hydrazones. The paper chromatographic method of Huelin (1952) was used to identify methyl ketones up to $\mathrm{C}_{7}$ and that of Klein \& de Jong (1956) for ketones from $C_{5}$ to $C_{15}$. Further identification of the 2,4-DNP hydrazones was possible by measurement of their light-absorption maxima in ethanol and particularly by fading studies of their spectra in alkaline ethanolic solution according to Jones, Holmes \& Seligman (1956).

Radioactive assays. Radioactive carbon dioxide was estimated by a modification of the method described by Chiriboga \& Roy (1962). The gas was absorbed on DEAE-cellulose paper (Whatman DE 20, free base form) impregnated with $20 \%$ KOH. DEAE-cellulose paper gave consistently higher and more reproducible results than Whatman 50 paper. The paper was removed from the Warburg flask, dried under an infra-red lamp, transferred to a counting vial containing $3 \mathrm{ml}$. scintillation fluid $(0.05 \%$ 2,5-diphenyloxazole $+0.03 \%$ 1,4-di[2-(5-phenyloxazolyl)] + benzene in toluene) and counted at room temperature in a liquid scintillation system (NE 8391, Nuclear Enterprises (G.N.), Ltd., Edinburgh).

Radioactivity taken up by the spores was estimated by pipetting $1 \mathrm{ml}$. of the reaction mixture on to a Millipore filter and washing the collected spores thoroughly with a solution of potassium octanoate $(0.05 \mathrm{~m})$ followed by distilled water. The spores were dried and counted as above. The Millipore filters used were completely transparent in the scintillation fluid.

Radioactive octanoic acid and heptan-2-one were estimated by pipetting $1 \mathrm{ml}$. of the reaction mixture into $2 \mathrm{ml}$. of 2,4-DNP hydrazine reagent, adding $2 \mathrm{ml}$. of $2 \mathrm{~N}-\mathrm{KOH}$ after $30 \mathrm{~min}$, and filtering the mixture on a Millipore filter. A suitable sample of the filtrate (usually $0 \cdot 1 \mathrm{ml}$.), containing the potassium salt of the radioactive octanoic acid, was transferred to a circular disc of DEAE cellulose paper, dried and transferred to a counting vial containing scintillation fluid. The 2,4-DNP hydrazone of heptan-2-one on the Millipore filter was then washed thoroughly with distilled water, dried and counted as above. 
Quenching corrections. These were established by the use of $\left[n^{14} \mathrm{C}\right]$-hexadecane as an internal standard. A quenching curve was prepared for the 2,4-DNP hydrazone of heptan-2-one, the quenching of radioactivity being proportional to the amount of 2,4-DNP hydrazone added up to a maximum of $0 \cdot 2 \mathrm{mg} . / 3 \mathrm{ml}$. scintillation fluid. The correction necessary to compensate for quenching was estimated from the quenching curve and also, as a check, by adding a known sample of standard $\left[n-{ }^{14} \mathrm{C}\right]$-hexadecane dissolved in toluene to the vial containing the radioactive 2,4 DNP hydrazone.

\section{RESULTS}

\section{Effect of washing the spores}

The rate of oxidation of fatty acids by washed young spores (4 or 5 days old) was slightly lower than with unwashed spores, but the ultimate yield of methyl ketone was not affected. The activity of older spores (6-10 days old) was however considerably decreased by washing. Zweig \& Devay (1959) found that the physiological responses of washed spores may be seriously modified, but in the present work the effect was considered to be the removal of stimulatory compounds which inevitably contaminate spores collected from an agar surface.

\section{Activation of spores}

The ability of washed spores to oxidize octanoic acid to heptan-2-one decreased markedly with age (Fig. 1). Only spores harvested 4 or 5 days after inoculation of

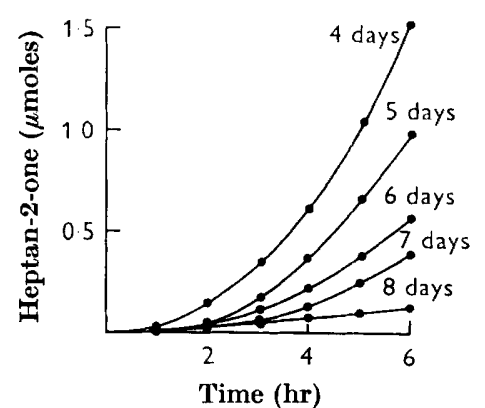

Fig. 1

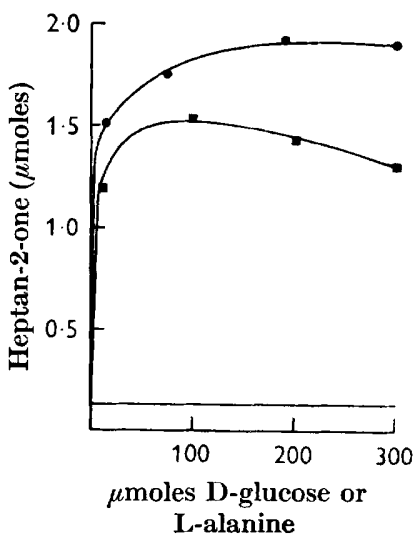

Fig. 2

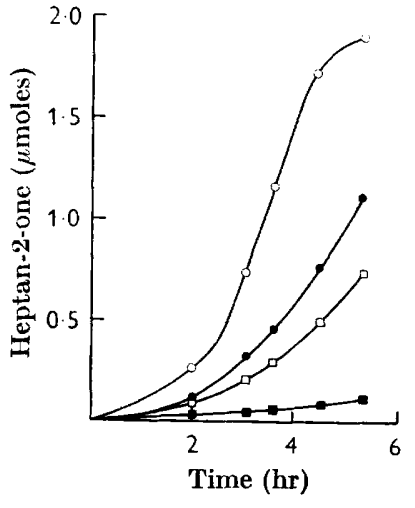

Fig. 3

Fig. 1. Effect of age of washed spores of Penicillium roqueforti $\left(1.5 \times 10^{9}\right)$ on ability to form heptan-2-one from octanoic acid (3 $\mu$ moles) at pH $5 \cdot 5$ (100 $\mu$ moles phosphate buffer). Total volume $3 \mathrm{ml}$.

Fig. 2. Effect of concentration of D-glucose (--) and L-alanine ( $\square-\square)$ on the formation of heptan-2-one from octanoic acid $(3 \mu$ moles) by washed 8-day spores of Penicillium roqueforti $\left(1.5 \times 10^{9}\right)$ at pH 5.5 $(100 \mu$ moles phosphate buffer $)$. Total volume $3 \mathrm{ml}$. Time of incubation $5 \mathrm{hr}$. The horizontal line represents the formation of heptan-2one in the absence of $\mathrm{D}$-glucose or L-alanine.

Fig. 3. The effect of Seitz-filtered solutions on heptan-2-one formation from octanoic acid by spores of Penicillium roqueforti. Each flask contained $1 \mathrm{ml}$. spore suspension $\left(1.5 \times 10^{9}\right.$ spores $), 1 \mathrm{ml}$. phosphate buffer (100 $\mu$ moles; $\left.\mathrm{pH} 5.5\right)$, and $1 \mathrm{ml}$. of water ( $\square-\square)$ or Seitz-filtered water $(\square-\square)$; glucose $(250 \mu$ moles) solution ( $-\bullet)$ or Seitzfiltered glucose solution $(\mathrm{O}-\mathrm{O})$. 
the Czapek-Dox agar oxidized octanoic acid readily. However, both oxygen uptake and methyl ketone formation by older spores (6-10 days old) were dramatically increased, after an initial lag period of 1 to $2 \mathrm{hr}$, by the addition of small amounts ( $1 \mu$ mole or less $/ 3 \mathrm{ml}$.) of certain sugars, in particular glucose, galactose, xylose or sucrose, and amino acids such as L-alanine, L-serine or L-proline. The degree of stimulation increased with concentration to an optimum of about $250 \mu$ moles $/ 3 \mathrm{ml}$. for glucose and $100 \mu$ moles $/ 3 \mathrm{ml}$. for alanine (Fig. 2). Very young spores were also activated by these specific sugars and amino acids but to a much smaller degree. On microscopic examination, the activated spores were unchanged morphologically.

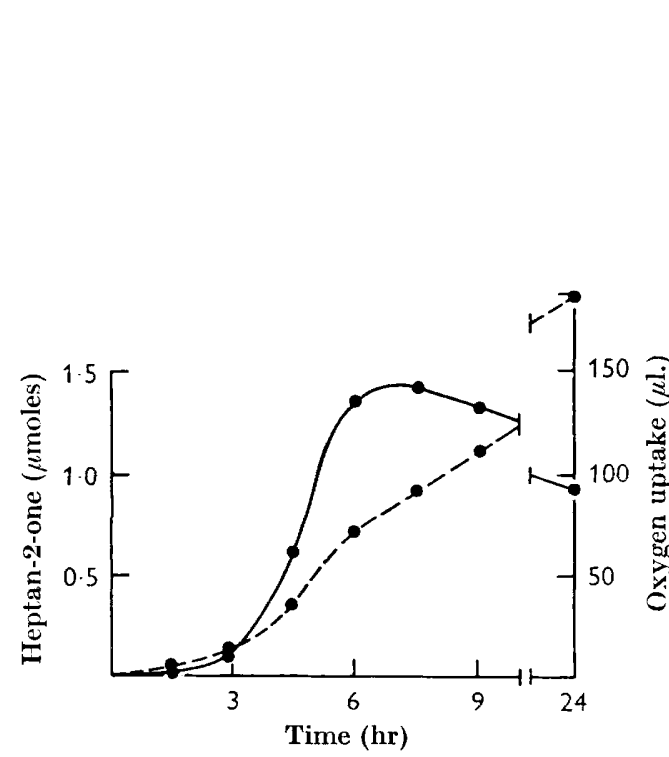

Fig. 4

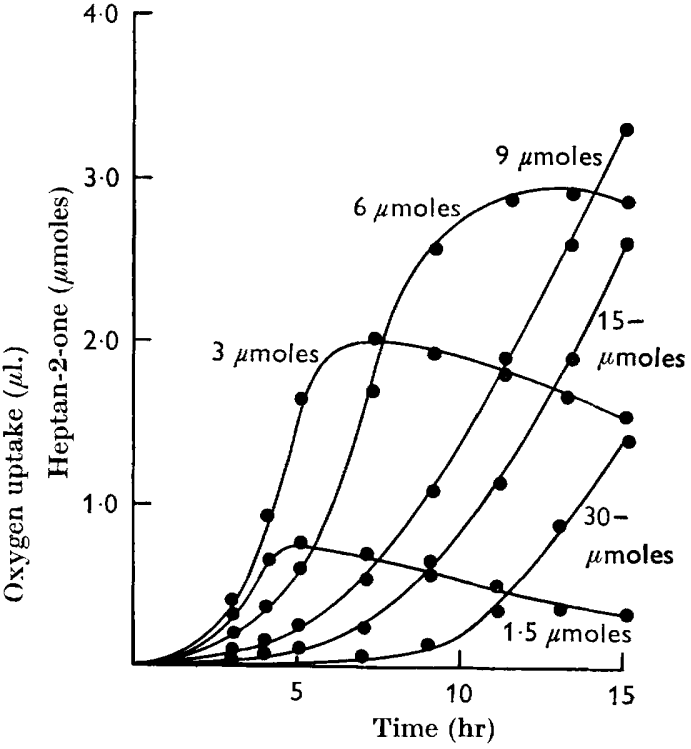

Fig. 5

Fig. 4. Oxygen uptake $(--\rightarrow)$ and formation of heptan-2-one $(-)$ from $3 \mu$ moles octanoic acid by washed 5 -day spores $\left(1.5 \times 10^{9}\right)$ of Penicillium roqueforti at $\mathrm{pH} 5.5$ (100 $\mu$ moles phosphate buffer). Total volume $3 \mathrm{ml}$.

Fig. 5. The formation of heptan-2-one from different concentrations of octanoic acid by washed 5-day spores $\left(1.5 \times 1^{9}\right)$ of Penicillium roqueforti at pH 5.5 (100 $\mu$ moles phosphate buffer). Total volume $3 \mathrm{ml}$.

Routinely, solutions of sugars and amino acids were Seitz filtered since they were found to be almost twice as effective in stimulating the oxidation of octanoic acid as solutions which had not been so filtered (Fig. 3). It was concluded that this was due to the presence of some unidentified factor dissolved from the filter pad since distilled water which had been Seitz filtered was also stimulatory. The Seitz filters (Ford 'Sterimats') were made of asbestos cellulose; and it may be relevant that Atkinson \& Allen (1958) extracted an unknown factor from cotton which permitted the rapid germination of rust uredospores.

Although spores of any age were activated by small amounts of specific sugars and amino acids, it was obviously preferable to follow the oxidation of fatty acids in the absence of other exogenous carbon sources. The experiments reported in this paper were therefore made with young spores, 4 or 5 days old, which required no stimu- 
latory agents. Maximum formation of heptan-2-one corresponded to the complete utilisation of the acid, after which the ketone itself was slowly metabolised (Fig. 4). This secondary metabolism proceeded more rapidly in the presence of ammonium ion or casamino acids.

\section{Effect of concentration of fatty acid}

The lag before heptan-2-one was detected lengthened as the concentration of acid was increased. Thus at $\mathrm{pH} 5 \cdot 5$, oxidation of $3 \mu$ moles octanoic acid began after a lag of $1 \mathrm{hr}$ and was complete in $7 \mathrm{hr}$, whereas there was a lag of $10 \mathrm{hr}$ when $30 \mu$ moles of

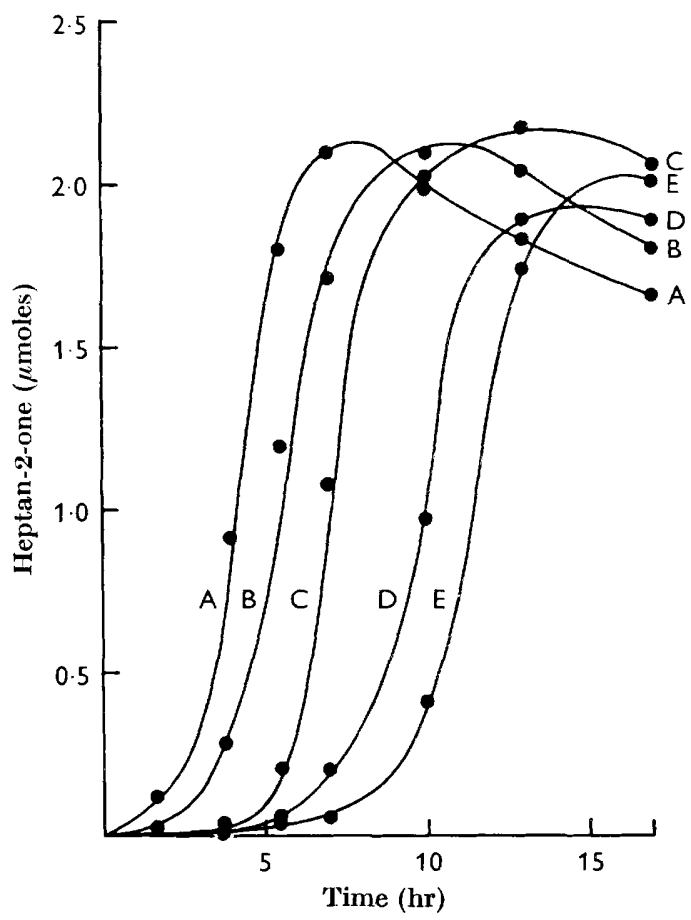

Fig. 6
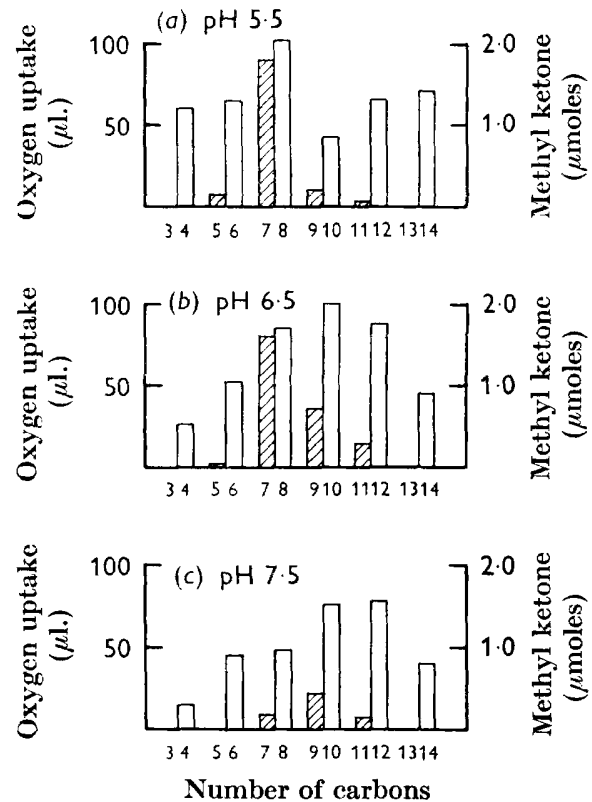

Fig. 7

Fig. 6. Penicillium roqueforti. The effect of spore concentration on the rate of formation of heptan-2-one from octanoic acid (3 $\mu$ moles) at pH 5.5 (100 $\mu$ moles phosphate buffer). Total volume $3 \mathrm{ml}$. Spore suspension A contained $1.5 \times 10^{9}$ spores. B, C, D and E contained one half, quarter, eighth and sixteenth, respectively, of this spore concentration.

Fig. 7. Oxygen uptake (unshaded bars) and formation of methyl ketones (shaded bars) by washed, 5-day spores of Penicillium roqueforti $\left(1.5 \times 10^{9}\right)$ in the presence of fatty acids $(3 \mu$ moles) at $(a) \mathrm{pH} 5.5,(b) \mathrm{pH} 6.5$ and $(c) \mathrm{pH} 7.5$ (100 $\mu$ moles phosphate buffer), Total volume $3 \mathrm{ml}$. Even carbon numbers refer to fatty acid substrates and odd carbon numbers to the corresponding methyl ketone formed with one less carbon atom.

octanoic acid were incubated with the same concentration of spores (Fig. 5). The same effect was obtained by varying the concentration of the spore suspension. Dilution of the spore suspension led to a marked increase in the lag before heptan-2-one was detected but, over an extended time, the diluted suspensions gave about the same yield as an undiluted one (Fig. 6). Moreover, the time taken to reach maximum yield of heptan-2-one from octanoic acid increased only two-fold when the spore 
suspension was diluted 16 times. The overall rate of formation of heptan-2-one/ spore therefore increased considerably on dilution of the spore suspension. Although no simple relationship existed between fatty acid concentration, the number of spores $/ \mathrm{ml}$. and the length of the lag period before methyl ketone was detected, it is evident that the amount of fatty acid available/spore determined the rate of oxidation.

\section{Effect of $p H$ value}

Maximum methyl ketone formation occurred between $\mathrm{pH} 5.5$ and $\mathrm{pH} 7.0$ when octanoic acid was the acid most readily oxidized (Fig. 7 ). The optimum $\mathrm{pH}$ value depended upon the concentration of fatty acid being oxidized, 1, 3 and $20 \mu$ moles octanoic acid giving maximum yields of heptan-2-one at $\mathrm{pH} 5 \cdot 8,6 \cdot 4$ and $6 \cdot 8$, respectively. The rate at which methyl ketones were formed decreased rapidly above pH 7.0. Decanoic acid gave the greatest yield of corresponding methyl ketone at pH 7.5. At $\mathrm{pH} 2 \cdot 5$ oxygen uptake and methyl ketone formation by spores in the presence of fatty acids were also considerably decreased, only octanoic acid giving measurable amounts of the corresponding methyl ketone (approximately $20 \%$ of the original acid after $6 \mathrm{hr}$ ).

The yields of methyl ketones obtained from fatty acids in this investigation were much higher than those reported by previous workers. Between $\mathbf{p H ~} \mathbf{5 . 5}$ and 6.5, up to $75 \%$ of the octanoate, $45 \%$ of the decanoate, $25 \%$ of the laurate and $5 \%$ of the hexanoate were ultimately oxidized to the corresponding methyl ketone. Only one methyl ketone was detected in each case. Methyl ketones were not detected when spores were incubated with butyrate or myristate at any $\mathrm{pH}$ value. The oxidation of the $\mathrm{C}_{6}$ to $\mathrm{C}_{12}$ fatty acids by spores followed the same pattern as in Fig. 3, i.e. increasing after an initial lag of 1-2 hr to a maximum after 6-7 hr. The subsequent decrease in rate of oxygen uptake and cessation of methyl ketone formation indicated the completion of fatty acid utilization.

\section{Effect of temperature}

Whereas oxygen uptake remained fairly constant between $24^{\circ}$ and $37^{\circ}$, the rate of formation of heptan-2-one from octanoic acid exhibited a sharp maximum at $27^{\circ}$ and decreased rapidly with rise in temperature (Table 1 ). Only $6 \%$ of the acid

Table 1. The variation with temperature of oxygen uptake and formation of heptan-2-one by Penicillium roqueforti spores incubated with octanoic acid at $p H 5 \cdot 5$

Each flask contained $1.5 \times 10^{9}$ spores, 5 days old, $100 \mu$ moles phosphate buffer $(\mathrm{pH} 5 \cdot 5)$, $3 \mu$ moles octanoic acid, distilled water to $3 \mathrm{ml}$. Time of incubation $5 \mathrm{hr}$.

$\begin{array}{crc}\begin{array}{c}\text { Temperature } \\ \left({ }^{\circ}\right)\end{array} & \begin{array}{c}\text { Oxygen } \\ \text { uptake } \\ (\mu \mathrm{l} .)\end{array} & \begin{array}{c}\text { Heptan-2-one } \\ (\mu \mathrm{moles})\end{array} \\ 18 & 3 & 0 \cdot 08 \\ 21 & 60 & 0 \cdot 44 \\ 24 & 85 & 1 \cdot 22 \\ 27 & 106 & 1 \cdot 92 \\ 30 & 101 & 1 \cdot 41 \\ 33 & 94 & 0 \cdot 63 \\ 37 & 90 & 0 \cdot 20\end{array}$


was oxidized to heptan-2-one after $5 \mathrm{hr}$ at $37^{\circ}$, and $40 \%$ after $24 \mathrm{hr}$. Spores incubated at $45^{\circ}$ for $30 \mathrm{~min}$. were subsequently unable to oxidize octanoic acid at $27^{\circ}$.

\section{Effect of aeration}

With low concentrations of octanoic acid ( $1 \mu \mathrm{mole} / 3 \mathrm{ml}$ ) the rate of formation of heptan-2-one was not affected by shaking. This was not surprising since the quantity of oxygen soluble in $3 \mathrm{ml}$. water at $27^{\circ}$ (about $1.4 \mu$ moles) is more than that theoretically required to oxidize $1 \mu$ mole octanoic acid completely to heptan2-one. With higher concentrations of octanoic acid, however, a considerable increase in rate of oxidation occurred when the reaction medium was shaken.

\section{Effect of absorption of carbon dioxide}

Methyl ketone formation was considerably increased when the small amounts of metabolic carbon dioxide evolved were not absorbed by $20 \% \mathrm{KOH}$; the yields of

Table 2. The effect of absorbing carbon dioxide on the formation of methyl ketones from fatty acids by spores of Penicillium roqueforti

Each Warburg flask contained $1.5 \times 10^{9}$ spores, 4 days old, $100 \mu$ moles phosphate buffer $(\mathrm{pH} \mathrm{6 \cdot 5)}$.

\begin{tabular}{|c|c|c|c|c|}
\hline \multirow{3}{*}{$\begin{array}{l}\text { Fatty acid } \\
(3 \mu \text { moles })\end{array}$} & \multicolumn{4}{|c|}{ Methyl ketones ( $\mu$ moles) } \\
\hline & \multicolumn{2}{|c|}{$4 \mathrm{hr}$} & \multicolumn{2}{|c|}{$8 \mathrm{hr}$} \\
\hline & $+\mathbf{K O H}$ & $-\mathbf{K O H}$ & $+\mathbf{K O H}$ & $-\mathrm{KOH}$ \\
\hline $\mathrm{C}_{6}$ & Nil & 0.08 & Nil & 0.09 \\
\hline $\mathrm{C}_{8}$ & $0 \cdot 70$ & $0 \cdot 85$ & $1 \cdot 46$ & $1 \cdot 70$ \\
\hline $\mathrm{C}_{10}$ & $0 \cdot 24$ & $\mathbf{0} \cdot \mathbf{3 3}$ & $0 \cdot 33$ & $0 \cdot 63$ \\
\hline $\mathrm{C}_{12}$ & $0 \cdot 09$ & $\mathbf{0 \cdot 2 6}$ & $0 \cdot 12$ & $0 \cdot 27$ \\
\hline
\end{tabular}

the corresponding methyl ketones from decanoic and lauric acids were then more than doubled (Table 2). The yield of heptan-2-one from octanoic acid however was less markedly increased by the presence of carbon dioxide.

\section{Effect of cations}

Neither manganese nor magnesium was required for oxidation, concentrations above $1 \mu \mathrm{mole} / \mathrm{ml}$. being increasingly inhibitory. Traces of copper, ferrous or ferric ions (less than $0.5 \mu \mathrm{mole} / \mathrm{ml}$.) slightly increased (up to $20 \%$ ) the rate of formation of heptan-2-one from octanoic acid between $\mathrm{pH} 6$ and 7 . Below $\mathrm{pH} 6$, however, the rate of formation was greatly decreased, concentrations above $1 \mu \mathrm{mole} / \mathrm{ml}$. completely inhibiting the oxidation. Potassium ion slightly accelerated (up to $20 \%$ ) the rate of formation of heptan-2-one, whereas sodium ion resulted in slightly higher overall yields. Ammonium ion (20 $\mu$ moles $/ \mathrm{ml}$.) decreased by about $25 \%$ the oxygen uptake and yields of heptan-2-one from octanoic acid.

\section{The effect of inhibitors on octanoate oxidation}

Chloramphenicol, which specifically inhibits protein synthesis (Gale \& Folkes, 1953), was without effect upon oxygen uptake or formation of heptan-2-one (Table 3). This indicated that no adaptive enzyme synthesis was taking place and 


\section{Oxidation of fatty acids by spores of Penicillium roqueforti}

that the lag period before oxidation occurred might be a result of permease or enzyme activation. Since the development of transport mechanisms is associated with oxidative phosphorylation (Quastel, 1964), 2,4-dinitrophenol (DNP) and sodium azide were tested as uncoupling agents. The formation of heptan-2-one and oxygen uptake decreased with increase in concentration of each inhibitor and were virtually eliminated at concentrations of $10^{-3} \mathrm{M}-2,4-\mathrm{DNP}$ and $10^{-4} \mathrm{M}$-sodium azide (Table 3). Malonate, in concentrations up to $0 \cdot 1 \mathrm{M}$ was without effect upon octanoate oxidation between $\mathrm{pH} 4.5$ and $6 \cdot 5$.

Table 3. The effect of 2,4-dinitrophenol, sodium azide and chloramphenicol on oxygen uptake and formation of heptan-2-one from octanoic acid (3 $\mu$ moles) by 5 -day-old spores of Penicillium roqueforti

Each flask contained $3 \mu$ moles octanoic acid, $1.5 \times 10^{9}$ spores, $100 \mu$ moles phosphate buffer (pH 5.5), inhibitor as below, water to $3 \mathrm{ml}$. Time of incubation $4 \mathrm{hr}$.

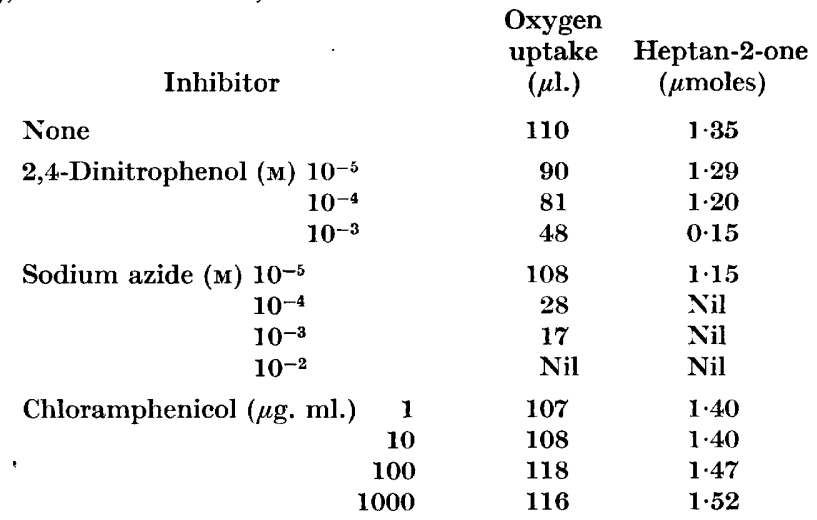

\section{Oxidation of $\left[1-{ }^{14} \mathrm{C}\right]$ and $[2-14 \mathrm{C}]$ octanoic acids}

The uptake of radioactivity by the spores from these acids was initially very slow, reaching a maximum of about $10 \%$ of the total activity after $2 \mathrm{hr}$ incubation. The rapid formation of heptan-2-one after this lag period was correlated with the equally rapid decrease of octanoic acid in the medium (Fig. 8).

The heptan-2-one from $\left[1-{ }^{14} \mathrm{C}\right]$ octanoic acid was not radioactive; heptan-2-one from $\left[2-{ }^{14} \mathrm{C}\right]$ octanoic acid was radioactive, the specific activity of the 2,4-DNP hydrazone being almost identical to that of the $[2-14 \mathrm{C}]$ octanoic acid added. The rate of appearance of ${ }^{14} \mathrm{C}$ in respiratory carbon dioxide from $\left[2-{ }^{14} \mathrm{C}\right]$ octanoic acid was very slow, less than $1 \%$ of the original activity appearing as carbon dioxide after $6 \mathrm{hr}$ incubation with spores. This was in marked contrast to the finding of Gehrig $\&$ Knight (1963) that approximately $60 \%$ of the activity of $\left[3-{ }^{14} \mathrm{C}\right]$ octanoate could be recovered as ${ }^{14} \mathrm{CO}_{2}$.

\section{Elimination of the lag period}

Spores which had been shaken with glucose or with amino acids for periods up to $3 \mathrm{hr}$, collected and washed on a Millipore filter with distilled water, were not able subsequently to oxidize octanoic acid to heptan-2-one without the usual time lag. However, spores which had been shaken for $3 \mathrm{hr}$ with octanoic acid, washed on a Millipore filter and taken up in the same amount of phosphate buffer, were able to 
oxidize a further $3 \mu$ moles of octanoic acid immediately (Fig. 9). The percentage of octanoic acid oxidized to heptan-2-one was approximately the same as with spores which had not been pre-incubated. The addition of glucose to the activated spores did not significantly increase the yield of heptan-2-one. As the octanoic acid was utilized the rate of oxygen uptake decreased with time, in contrast to the increase in oxygen uptake that occurred with non-activated spores. Pre-incubation of the spores with decanoic and lauric acids also eliminated the lag phase when the spores were re-incubated with octanoic acid indicating that the three acids utilize the same permease system.

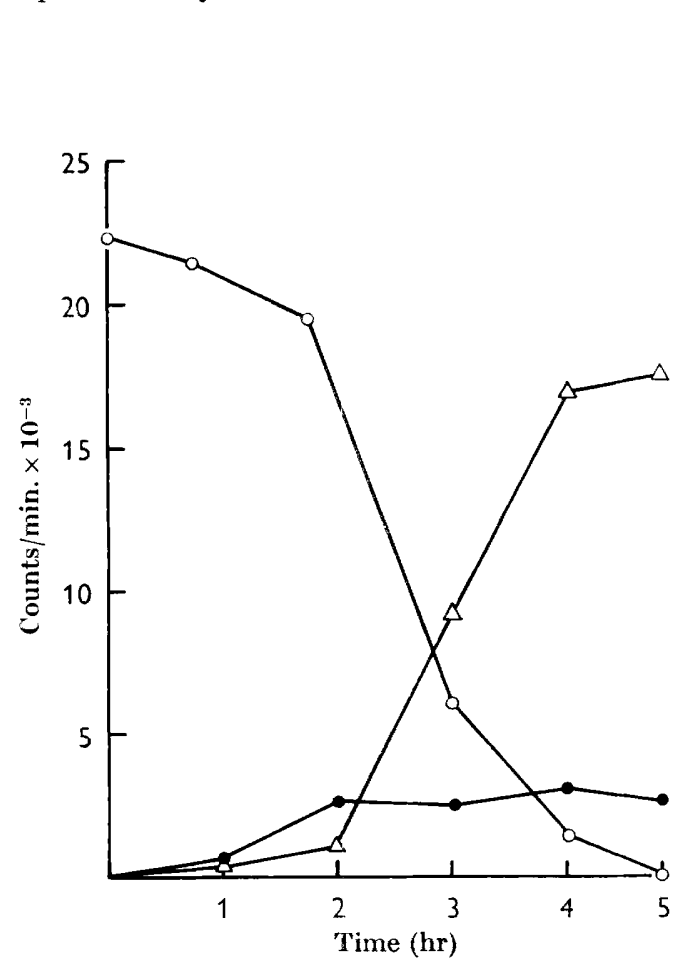

Fig. 8

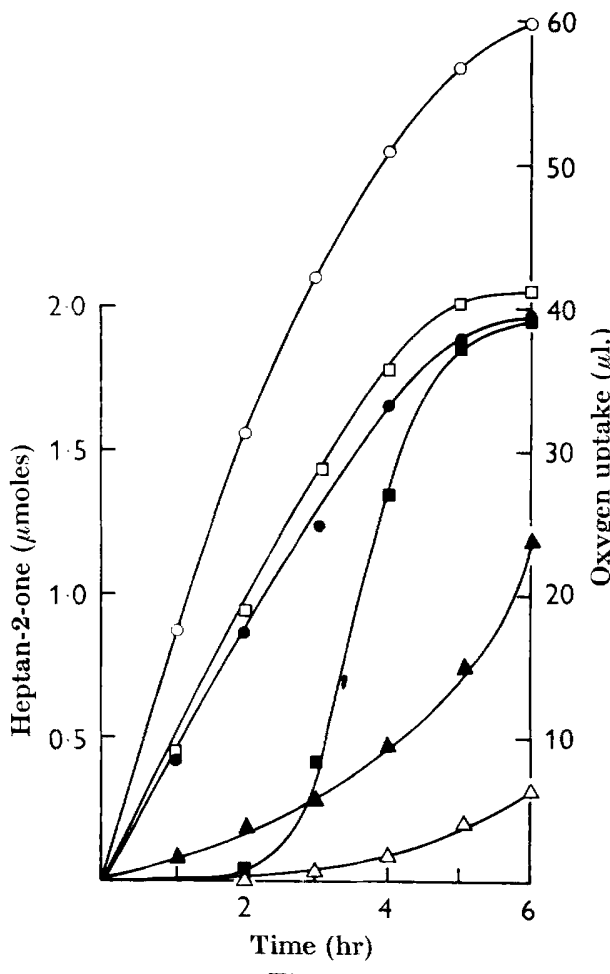

Fig. 9

Fig. 8. Distribution of radioactivity during the incubation of $3 \mu$ moles $2-{ }^{14} \mathrm{C}$-octanoic acid (initial count of 22,500 counts $/ \mathrm{min}$ ) with washed spores $\left(1.5 \times 10^{9}\right)$ at $\mathrm{pH} 5.5(100$ $\mu$ moles phosphate buffer). Radioactivity in $2{ }^{14} \mathrm{C}$-octanoic acid, $\mathrm{O}-\mathrm{O} ; 1^{-14} \mathrm{C}$-heptan-2one, $\triangle-\triangle$; spores,

Fig. 9. Formation of heptan-2-one from octanoic acid ( $3 \mu$ moles) by activated spores ( $-\bullet$ ), non-activated spores $(\triangle-\triangle)$, activated spores $+250 \mu$ moles glucose $(\square-\square)$, non-activated spores $+250 \mu$ moles glucose $(\square-\square)$. Oxygen uptake by activated spores $(O-O)$ and non-activated spores $(\Delta-\Delta)$. Each flask contained $1.5 \pm 10^{9}$ spores $(6$ days old, washed) and $100 \mu$ moles phosphate buffer, pH 5.5.

\section{Cell-free extracts}

A thick paste of spores and sand ground with buffer (see Methods) yielded an extract that oxidized low concentrations of octanoic acid $(0.5 \mu \mathrm{moles} / \mathrm{ml}$.) very slowly. The rate of oxidation was almost linear over a period of $40 \mathrm{hr}$, to give a yield of up to $50 \%$ heptan-2-one, which was then itself completely metabolized over a further $48 \mathrm{hr}$. 
Disintegration of a concentrated spore suspension with ballotini beads in a Mickle tissue disintegrator operating at maximum amplitude for times up to $1 \mathrm{hr}$ destroyed the ability of the treated suspension to take up oxygen or to produce heptan-2-one from octanoic acid. Spores treated with various concentrations of cetyl trimethylammonium bromide, sodium lauryl sulphate or toluene were also totally inactivated.

\section{DISCUSSION}

The existence of a lag phase in the oxidation of fatty acids by spores of Penicillium roqueforti has been previously reported (Lawrence, 1965 a). The lengthening of this lag period by increasing either the concentration of the acid or decreasing the number of spores shows clearly that the relationship of spore numbers to the initial fatty acid concentration determined the rate of oxidation. A high concentration of fatty acid that initially appears to be toxic may, after an extended lag period, be oxidized as completely as a lower concentration of acid. Pre-incubation of young spores with octanoic acid for 2-3 hr eliminates the lag phase completely when the spores are subsequently re-incubated with more octanoic acid.

The amount of oxygen taken up by the spores in the oxidation of octanoic acid is about twice that theoretically needed for complete conversion to heptan-2-one. This might be an indication of the energy required either for the synthesis of enzymes or for the activation of dormant permease or enzyme systems. It seems more likely however that the lag period in oxidation is a consequence of the activation of preformed proteins rather than of induced enzyme synthesis, since chloramphenicol, a specific inhibitor of protein synthesis (Gale \& Folkes, 1953), did not prevent oxygen uptake and the formation of methyl ketones. The ability of washed spores to oxidize octanoic acid decreased markedly with age, presumably because permeases and enzymes became increasingly de-activated in older spores. The finding that small amounts of specific sugars and amino acids stimulated the oxidation of the fatty acids and the shortening of the lag phase suggests that these compounds are metabolized more readily than others to yield either energy or metabolic products essential for the activation process.

Since cell-free extracts of spores, although not very active, were able to oxidize fatty acids slowly, it would appear that the enzymes responsible are not dormant in young spores but that the lag period in oxidation is the need for the activation of permeases. The elimination of the lag phase by pre-incubation of the spores with octanoic acid, but not with glucose or casamino acids, also suggests that permease formation is involved. The oxidation of fatty acids was also significantly decreased by non-aeration of the incubation medium or the addition of metabolic inhibitors such as sodium azide and 2,4-DNP, factors which have been shown to inhibit transport mechanisms in other micro-organisms (Cohen \& Monod, 1957; Leach \& Snell, 1960; Harvey \& Collins, 1962 ; Scholefield, 1964). The linking of phosphorylation with transport mechanisms, possibly with the formation or stability of the transport carrier and the production of ATP (Quastel, 1964), may be of particular importance in the oxidation of fatty acids by spores, since Pressman \& Lardy (1956) have shown that saturated fatty acids are themselves able to uncouple phosphorylation. They found that myristic acid exhibited the greatest uncoupling activity, which diminished progressively as the fatty acid chain was lengthened or shortened. 
This decrease in uncoupling activity from myristic to octanoic acid may therefore be a factor in the progressive increase in the yield of corresponding methyl ketone when these acids are incubated with spores. No methyl ketone was obtained from myristic acid, up to $25 \%$ from lauric acid, $45 \%$ from decanoic acid and $75 \%$ from octanoic acid. The rate at which methyl ketones are formed decreased rapidly above pH $7 \cdot \mathbf{0}$, indicating that only the unionized form of the acid is involved.

The heptan-2-one formed during the oxidation of $\left[1-{ }^{14} \mathrm{C}\right]$-octanoic acid was not radioactive, showing that the carbon atom from the carboxyl group is lost during the decarboxylation. Similarly, the finding that heptan-2-one from $[2-14 \mathrm{C}]$ octanoic acid was radioactive affords strong evidence for oxidation at the $\beta$-position. However, only heptan-2-one was detected when octanoic acid was oxidized, although the classical pathway of $\beta$-oxidation allows the formation of $\beta$-oxo acyl esters of octanoic, hexanoic and butanoic acids, and one might expect the subsequent formation of all three corresponding methyl ketones. The absence of thiolase from the spores, or its greatly decreased activity, would explain the subsequent detection of heptan-2-one alone, since then only the first $\beta$-oxo acyl ester would be formed. Thiolase activity, being dependent upon coenzyme $\mathbf{A}$ availability, would be greatly inhibited if the concentration of coenzyme in the spores were limited and could not be recycled, as in other fatty acid oxidising systems (Green, 1963), via the citric acid cycle. The extremely low rate of conversion of $\left[2-{ }^{14} \mathrm{C}\right]$ octanoic acid to radioactive carbon dioxide and the insensitivity of the oxidation to malonate indicates that neither the citric acid cycle nor any other active terminal respiratory pathway is operative in the first few hours of spore activation. The de-acylation of a $\beta$-oxo acyl ester would regenerate the limited amount of coenzyme available, thus allowing more acyl ester of the fatty acid to be formed.

Since the formation of methyl ketone was stimulated by the small amounts of evolved metabolic carbon dioxide, it is possible that the $\beta$-oxo acid decarboxylases have a further function in that they provide a source of carbon dioxide. Low concentrations of carbon dioxide have been shown to stimulate the germination of fungal spores (Yaganita, 1957; Farkas \& Ledingham, 1959; Vakil, Raghavendra Rao \& Bhattacharyya, 1961) which supports the view (Lawrence, 1965a) that compounds capable of stimulating the oxidation of fatty acids by spores are also likely to stimulate the germination of non-activated spores.

The technical assistance of Miss P. Gorman is gratefully acknowledged.

\section{REFERENCES}

Atrinson, T. G. \& Allen, P. J. (1958). Germination of wheat stem rust uredospores en masse. Plant Physiol. 33, Suppl. ix.

Chiriboga, J. \& Roy, D. N. (1962). Rapid method for determination of decarboxylation of compounds labelled with carbon-14. Nature, Lond. 193, 684.

Cohen, G. N. \& Monod, J. (1957). Bacterial permeases. Bact. Rec. 21, 169.

Farkas, G. L. \& Ledingham, G. A. (1959). The relation of self-inhibition of germination to the oxidative metabolism of stem rust uredospores. Can. J. Microbiol. 5, 141.

Franke, W. \& Heinen, W. (1958). Zur Kenntnis des Fettsäureabbaus durch Schimmelpilze. I. Über die Methylketonbildung durch Schimmelpilze. Arch. Mikrobiol. 31, 50.

Franke, W., Platzeck, A. \& Eichrorn, G. (1962). Zur Kenntnis des Fettsäureabbaus durch Schimmelpilze. IV. Versuche zum weiteren Umsatz der Methylketone. Arch. Mikrobiol. 41, 154. 
Gale, E. F. \& Folkes, J. P. (1953). Actions of antibiotics on nucleic acid and protein synthesis in Staphylococcus aureus. Biochem. J. 53, 493.

Gehrig, R. F. \& KNIGHT, S. G. (1963). Fatty acid oxidation by spores of Penicillium roqueforti. Appl. Microbiol. 11, 166.

Green, E. F. (1963). Fatty acid oxidation. Progr. Chem. Fats \& other Lipids, 6, 89.

Harvey, R. J. \& Coluins, E. B. (1962). Citrate transport system of Streptococcus diacetilactis. J. Bact. 83, 1005.

HuElin, F. E. (1952). Volatile products of apples. III. Identification of aldehydes and ketones. Aust. J. Sci. (Ser. B), 5, 328.

Jones, L. A., Holmes, J. C. \& Seligman, R. B. (1956). Spectrophotometric studies of some 2,4-dinitrophenylhydrazones. Analyt. Chem. 28, 191.

Krein, F. \& DE Jong, K. (1956). Paper chromatography of 2,4-dinitrophenyl-hydrazones of aliphatic carbonyl compounds. Rec. trav. chim. 75, 1285.

Lawrence, R. C. (1965a). Activation of spores of Penicillium roqueforti. Nature, Lond. 208, 801 .

LAWRENCE, R. C. (1965b). Use of 2,4-dinitrophenylhydrazine for the estimation of micro amounts of carbonyls. Nature, Lond. 205, 1313.

LEACH, F. R. \& SNELL, E. E. (1960). The absorption of glycine and alanine and their peptides by Lactobacillus casei. J. biol. Chem. 235, 3523.

MetcalF, L. D. (1960). Gas chromatography of unesterified fatty acids using polyester columns treated with phosphoric acid. Nature, Lond. 188, 142.

Quastel, J. H. (1964). Transport reactions at the cell membrane. Can. J. Biochem. 42, 907.

Pressman, B. C. \& Lardy, H. A. (1956). Effect of surface active agents on the latent ATPase of mitochondria. Biochim. biophys. Acta 21, 458.

Reid, E. E. \& Ruнoff, J. R. (1944). Organic Synthesis. Ed. by H. A. Blatt, vol. 2. New York: John Wiley and Sons.

Scholefield, P. G. (1964). The role of adenosine triphosphate in transport reactions. Can. J. Biochem. 42, 917.

Stokoe, W. N. (1928). The rancidity of coconut oil produced by mould action. Biochem. $J$. $22,80$.

Thaler, H. \& Geist, G. (1939). The chemistry of ketone rancidity. I. Decomposition of fatty acids by Penicillium glaucum. Biochem. $Z$. 302, 121.

Vakil, J. R., Raghavendra Rao, M. R. \& Bhattacharyya, P. K. (1961). Effect of carbon dioxide on the germination of conidiospores of Aspergillus niger. Arch. Mikrobiol. 39, 53.

Yanagita, T. (1957). Biochemical aspects of the germination of conidiospores of Aspergillus niger. Arch. Mikrobiol. 26, 329.

Zweig, G. \& Devay, J. E. (1959). On the biosynthesis of gibberellins from $\mathrm{C}^{12}$ substrates by Fusarium moniliforme. Mycologia 51, 877. 